\title{
Pengaruh Model Pembelajaran Course Review Horay Berbantuan Media Visual Terhadap Hasil Belajar Matematika
}

\author{
Ni Made Dewi Trisna Yanti1 ${ }^{*}$ I Nyoman Laba Jayanta², I Made Suarjana ${ }^{3}$ \\ 123 Program Studi Pendidikan Guru Sekolah Dasar, Universitas Pendidikan Ganesha, Singaraja, Indonesia
}

\begin{abstract}
Abstrak
Rendahnya hasil belajar matematika pada siswa kelas IV,kurangnya penggunaan model dan media dalam proses pembelajaran di kelas, interaksi dan kerjasama siswa dalam menyelesaikan suatu permasalahan di dalam kelompok masih kurang, Siswa kurang aktif dalam proses pembelajaran, kreativitas berfikir siswa dalam menjawab soal masih kurang. Sehingga penelitian ini bertujuan untuk mengetahui pengaruh yang signifikan model pembelajaran Course Review Horay berbantuan media visual terhadap hasil belajar matematika kelas IV. Penelitian ini berjenis penelitian ekperimen semu dan menngunakan rancangan non-equivalent posttest control grup design. Populasi dalam penelitian ini adalah seluruh siswa kelas IV yang berjumlah 41 orang. Berdasarkan analisis data hasil perhitungan uji-t diperoleh thitung= 2,65 sedangkan nilai ttabel pada taraf signifikan $5 \%$ dengan derajat kebebasan $(n 1+n 2-2)=22+19-2=39$ adalah 2,02, Berdasarkan thitung $=2,65>$ ttabel $=2,02$ maka $\mathrm{H} 0$ ditolak atau terdapat pengaruh yang signifikan model pembelajaran Course Review Horay berbantuan media visual terhadap hasil belajar matematika siswa kelas IV SDN di gugus VII Kecamatan Abang Kabupaten Karangasem Tahun Pelajaran 2019/2020.
\end{abstract}

\begin{abstract}
In the learning process in class is very important in the success of education. This study aims to determine the significant effect of students who take the Course Review Horay learning model assisted by visual media on the learning outcomes of grade IV mathematics learning at SD Negeri in Cluster VII Abang District in the academic year 2019/2020. This research is a quasi-experimental study and uses a non-equivalent posttest control group design. Based on data analysis the results of the t-test results obtained tcount $=2.65$ while the value of ttable at a significant level of $5 \%$ with degrees of freedom $(n 1+n 2-2)=22+19-2=39$ is 2.02 , based on tcount $=2,65>$ ttable $=2.02$, then $\mathrm{H} 0$ is rejected or there is a significant influence of students who follow the Course Review Horay learning model assisted by visual media on the mathematics learning outcomes of Grade IV SDN students in group VII Abang Subdistrict, Karangasem Regency 2019/2020 Academic Year.
\end{abstract}

Keywords:

Course Review Horay, learning outcomes, mathematics

\footnotetext{
${ }^{*}$ Corresponding author. 


\section{PENDAHULUAN}

Pendidikan sangat berperan penting dalam meningkatkan sumber daya manusia. Pendidikan merupakan sarana dan wahana yang dapat membentuk karakter manusia kedepannya. Pendidikan yang bermutu akan melahirkan generasi yang cerdas serta mempunyai skill yang dapat di kembangkan. Naharir, et all (2018) mengungkapkan pendidikan berfungsi untuk membentuk warga masyarakat menjadi baik, mengembangkan kemampuan dan membentuk watak, kepribadian serta peradaban yang bermartabat dalam hidup manusia. Menurut Jayanti (2017) bahwa pendidikan menjadi suatu perubahan yang sangat penting bagi seorang manusia untuk membentuk peningkatan yang lebih baik dan mempunyai pengaruh positif bagi perkembangan individu itu sendiri. Dalam standar proses pendidikan mempunyai keterkaitan dengan pelaksanaan pembelajaran, yang artinya dalam sebuah standar proses pendidikan memahami materi yang disampaikan.

Dalam pendidikan tidak lepas dengan adanya proses pembelajaran disekolah dan interaksi antara guru dengan siswa. Dalam proses pembelajaran guru harus lebih kreatif dalam mengembangkan metode dan teknik dalam mengajar agar pembelajaran menjadi lebih menarik dan diminati oleh siswa. Selain itu agar lebih efektif dan ideal dalam pembelajaran siswa diharapkan ikut terlibat langsung dengan memberikan kesempatan siswa untuk aktif berfikir dan mengalami pengalaman langsung dalam belajarnya contohnya pada mata pelajaran matematika. Pada pembelajaran matematika siswa dituntut harus berpikir lebih kritis dalam menyelesaikan soal yang diberikan oleh guru.

Pembelajaran matematika di SD merupakan mata pelajaran yang wajib. Matematika pada jenjang SD adalah dasar yang harus dipelajari dan dipahami oleh siswa. Dalam proses pembelajaran matematika, siswa diharapkan dapat memahami materi yang di pelajari agar hasil belajar meningkat. Maka dari itu keaktifan siswa sangat berpengaruh dalam proses pembelajaran. Pada kurikulum 2013 siswa dituntut berperan aktif dalam mengikuti proses pembelajaran.

Sundari (2016) menyatakan matematika adalah salah mata pelajaran yang penerapannya mampu menghadirkan daya berpikir kritis siswa. Selain itu dalam mempelajari matematika harus bersifat kontinyu, rajin dan disiplin serta memerlukan pemahaman konsep yang kuat sehingga dapat diterapkan pada pelajaran berikutnya. Jika sejak awal mata pelajaran matematika sudah kurang diminati maka untuk selanjutnya siswa akan mengalami kesulitan dalam proses pembelajaran. Hingga saat ini matematika masih dipandang sebagai mata pelajaran yang sulit, meskipun demikian dalam dunia pendidikan pelajaran matematika harus tetap dipelajari guna ketuntasan belajar siswa. Sapta (2016) menyatakan bahwa matematika adalah salah satu cabang ilmu yang sangat penting. Karena peranannya yang begitu besar dalam dunia pendidikan sehingga matematika menjadi pelajaran yang wajib diikuti di semua jenjang pendidikan yang ada. Oleh karena itu siswa harus memahami materi matematika.

Pada kenyataanya dalam proses pembelajaran matematika masih belum maksimal. Hal ini disampaikan oleh Kusfabianto, et all (2019) yang menyatakan bahwa hasil ulangan siswa mata pelajaran matematika, diperoleh keterangan bahwa keaktifan siswa menunjukkan hasil yang rendah dikarenakan guru lebih banyak cemarah ketika menjelaskan materi pelajaran dan memberikan contoh-contoh soal disertai rumus cara mengerjakannya. Siswa tidak diberikan kesempatan untuk mengkonstruksi sendiri konsep rumus-rumus tersebut sehingga ketika siswa menghadapi soal yang berbeda siswa bingung untuk mengerjakannya. Ningrum, et all (2019) menyatakan hasil belajar matematika merupakan hasil belajar siswa yang paling rendah jika dibandingkan dengan mata pelajaran lainnya. Hasibuan, (2019) menyatakan kegiatan pembelajaran matematika yang dilaksanakan hanya memposisikan siswa sebagai pendengar ceramah gguru, sehingga pembelajaran menjadi kurang optimal. Suriati, et all (2019) menyatakan siswa juga susah buat diatur dan lebih cepat merasa bosan dengan apa yang disampaikan oleh guru.

Berdasarkan hasil observasi yang telah dilakukan pada tanggal 16 oktober 2019 di Gugus VII Kecamatan Abang menunjukkan bahwa hasil belajar matematika masih rendah dan dibawah KKM hal itu disebabkan, 1) Kegiatan pembelajaran masih bersifat satu arah, siswa masih berpusat kepada guru sebagai sumber informasi, 2) Kurangnya penggunaan model dalam proses pembelajaran, 3) Guru dalam mengajar masih kurang menggunakan media pembelajaran, 4) Kurangnya pemahaman siswa terhadap konsep matematika, 5) Hasil belajar matematika siswa yang masih rendah dan di bawah KKM.

Tahap kedua melaksanakan kegiatan wawancara pada tanggal 18 oktober 2019, di Gugus VII Kecamatan Abang. Berdasarkan wawancara yang telah dilakukan diperoleh beberapa informasi yang mengakibatkan hasil belajar matematika dibawah KKM, 1) kurangnya keaktifan siswa dalam proses pembelajaran matematika, siswa yang aktif dalam pembelajaran hanyalah siswa yang pintar, 2) Interaksi dan kerjasama siswa dalam menyelesaikan suatu permasalahan di dalam kelompok masih kurang, 3) Guru menyatakan kurangnya kesiapan dalam penggunaan model dan media pembelajaran di karenakan banyak kesibukan. 4) Guru menyatakan kreativitas berfikir siswa dalam menjawab soal masih kurang. 
Tahap selanjutnya melaksanakan kegiatan pengumpulan dokumentasi pada tanggal 18 oktober 2019. Berdasarkan pencatatan dokumen diperoleh informasi data hasil belajar matematika. Pada data tersebut menunjukan renda hnya hasil Penilaian Tengah Semester (PTS) matematika dan berada di bawah KKM. Rata-rata KKM di setiap sekolah yaitu 60-62. Data lebih rinci dapat dilihat pada Tabel 1.

Tabel 1. Rata-rata Nilai PTS Matematika pada kelas IV Gugus VII Kecamatan Tahun Pelajaran 2019

\begin{tabular}{|c|c|c|c|c|c|c|c|}
\hline \multirow{3}{*}{ No } & \multirow{3}{*}{ Nama Sekolah } & \multirow{3}{*}{$\begin{array}{l}\text { Jml } \\
\text { Siswa }\end{array}$} & \multirow{3}{*}{ KKM } & \multicolumn{4}{|c|}{ Jumlah Siswa Pencapaian KKM } \\
\hline & & & & \multicolumn{2}{|c|}{$\begin{array}{l}\text { Siswa yang mencapai } \\
\text { KKM }\end{array}$} & $\begin{array}{lr}\text { Siswa yang } \\
\text { mencapai }\end{array}$ & \multirow{2}{*}{ tidak } \\
\hline & & & & Siswa & $\%$ & Siswa & \\
\hline 1. & SD N 1 Ababi & 17 & 60 & 10 & $58 \%$ & 7 & $41 \%$ \\
\hline 2. & SD N 2 Ababi & 22 & 60 & 9 & $40 \%$ & 13 & $59 \%$ \\
\hline 3. & SD N 3 Ababi & 19 & 60 & 10 & $52 \%$ & 9 & $47 \%$ \\
\hline 4. & SD N 5 Ababi & 8 & 61 & 6 & $75 \%$ & 2 & $25 \%$ \\
\hline 5. & SD N 6 Ababi & 20 & 61 & 10 & $50 \%$ & 6 & $30 \%$ \\
\hline 6. & SD N 7 Ababi & 16 & 62 & 12 & $75 \%$ & 5 & $31 \%$ \\
\hline 7. & SD N 8 Ababi & 8 & 60 & 5 & $62 \%$ & 3 & $37 \%$ \\
\hline
\end{tabular}

(Sumber: Wali kelas IV di SD Gugus VII Kecamatan Abang)

Berdasarkan pada tabel 1 jumlah seluruh siswa kelas IV di gugus VII Kecamatan Abang sebanyak 107 siswa. Siswa yang belum mencapai KKM sebanyak 62 orang dan siswa yang sudah mencapai KKM sebanyak 45 orang. Jadi dapat disimpulkan bahwa hasil belajar matematika siswa kelas IV di gugus VII Kecamatan Abang masih rendah dan di bawah KKM.

Dalam mengatasi permasalahan tersebut diperlukan guru yang kreatif dan inovatif dalam mengemas pembelajaran matematika supaya menjadi lebih menarik dan tidak membosankan. Solusi yang tepat untuk permasalahan tersebut adalah dengan penggunaan model dan media pembelajaran yang tepat. Model dan media pembelajaran yang tepat untuk mata pelajaran matematika dalam meningkatkan hasil belajar siswa yang masih rendah yaitu dengan menggunakan model pembelajaran Course Review Horay dan media Visual. Model pembelajaran Course Review Horay dan media visual diduga dapat menambah semangat dan memperbaiki hasil belajar siswa dalam proses pembelajaran, karena model ini memberikan peluang cukup besar untuk siswa ikut berperan aktif dalam proses pembelajaran. Model ini menekankan kreativitas siswa berpikir kritis dalam menjawab soal. Menurut Jatiyasa (2020) Jatiyasa (2020) menyatakan Model pembelajaran CRH merupakan salah satu pembelajaran kooperatif yaitu kegiatan belajar mengajar dengan cara pengelompokkan siswa ke dalam kelompokkelompok kecil. Putri, et all (2019 model CRH merupakan suatu pola atau perencanaan yang menguji pemahaman konsep siswa dengan menggunakan kota yang diisi dengan kotak serta diberi nomor untuk menuliskan jawabannya dan setiap siswa yang mendapatkan jawaban benar diwajibkan berteriak "horay" atau yel-yel yang disukai.

Huda (dalam Mediatati dan Suryaningsih, 2016) menjelaskan bahwa model pembelajaran Course Review Horay membantu siswa untuk memahami konsep dengan baik melalui diskusi kelompok karena dengan model ini akan dilakukan pengujian pemahaman siswa pada materi pelajaran dan langsung dibahas sehingga siswa dapat langsung mengetahui jawabannya benar dan salah. Model ini melatih daya berpikir siswa dalam menyelesaikan masalah, siswa yang paling terdahulu mendapatkan tanda benar berteriak hore atau yel-yel lainnya. Model pembelajaran Course Review Horay juga memiliki kelebihan diantaranya menciptakan suasana pembelajaran yang menyenangkan karena diselingi dengan hiburan dan melatih kerja sama dalam menjawab soal yang diberikan oleh guru secara kelompok. Nureva, et all (2019) Course Review Horay adalah salah satu tipe dari model pembelajaran yang dapat mendorong siswa untuk ikut aktif dalam belajar dan mendukung siswa dalam proses pembelajaran. Sejalan dengan penelitian Aprilianawati, et all (2019) bahwa dengan menggunakan model pembelajaran Course Review Horay berbantuan Lectora lebih baik dari pada model pembelajaran konvensional. Terdapat perbedaan prestasi belajar matematika siswa yang memiliki gaya belajar visual, auditorial, atau kinestetik.

Model pembelajaran Course Review Horay berbantuan media visual sangat membantu meningkatkan hasil belajar matematika. Sadiman, dkk (2012) menyatakan media visual termasuk media grafis berfungsi untuk menyalurkan pesan dari sumber kepenerima pesan. Saluran yang dipakai menyangkut panca indera penglihatan. Pesan yang disampaikan dituangkan ke dalam komunikasi visual. 
Media visual dalam pembuatannya sangat sederhana dan mudah yang termasuk media visual yaitu gambar, sketsa, diagram, bagan/chart, grafis, kartun, poster, peta/globe, papan flannel.

Berdasarkan latar belakang diatas, maka peneliti tertarik untuk melaksanakan penelitian dengan judul " Pengaruh Model Pembelajaran Course Review Horay berbantuan media visual terhadap hasil belajar matematika di Gugus SD Negeri Kecamatan Abang Tahun Pelajaran 2019/2020".

\section{METODE PENELITIAN}

Penelitian ini dilaksanakan di kelas IV SD di Gugus VII kecamatan Abang. Pelaksanan penelitian ini pada Semester II tahun pelajaran 2019/2020, tepatnya pada bulan Maret 2020. Disain penelitian yang digunakan dalam penelitian ini adalah non-equivalent post test only control group design. Populasi dalam penelitian ini adalah siswa kelas IV SD Gugus VII Kecamatan Abang Kabupaten Karangasem yang terdiri 7 SD Negeri dengan jumlah siswa keseluruhan 121 siswa yang akan diuji kesetaraannya. Teknik pengambilan sampel dalam penelitian ini menggunkan teknik simple random sampling. Sampel yang di random dipenelitian ini adalah kelas IV di SD Gugus VII Kecamatan Abang Kabupaten Karangasem. Melalui simple random sampling, diperoleh kelas IV di SDN 2 Ababi sebagai kelompok eksperimen dan kelas IV di SDN 3 Ababi sebagai kelompok kontrol. Kelompok ekperimen akan diberikan perlakuan dengan menerapkan model pembelajaran Course Review Horay berbantuan media visual, sedangkan untuk kelompok kontrol belajar secara konvensional.

Untuk menentukan kesetaraannya dilakukan uji kesetaraan dengan cara menganalisis nilai ulangan tengah semester pada mata pelajaran matematika tahun pelajaran 2019/2020. Berdasarkan analisis varians dengan uji ANAVA satu jalur diperoleh thitung $=2,65$ sedangkan nilai ttabel pada taraf signifikan $5 \%$ dengan derajat kebebasan $(n 1+n 2-2)=22+19-2=39$ adalah 2,02, Berdasarkan $t_{\text {hitung }}=2,98>t_{\text {tabel }}$ = 2,02 maka $\mathrm{H}_{0}$ diterima dan $\mathrm{H}_{1}$ diterima.

Data yang digunakan dalam penelitian ini adalah tes, tes tersebut disusun berdasarkan kisi-kisi soal yang telah dibuat sesuai dengan KD dan indikator. Terdiri 18 soal pilihan ganda, mata pelajaran yang akan di bahas adalah matemtia tentang hubungan antar garis. Kisi-kisi yang berupa instrumen akan diuji terlebih dahulu dengan uji validitas isi menggunakan rumus Gregory, validitas butir tes menggunakan rumus korelasi point biserial, reliabilitas tes menggunakan KR-20, daya beda tes, dan tingkat kesukaran tes. Hasil tes uji soal tersebut

\section{ANALISIS DAN PEMBAHASAN}

Setelah kelompok ekperimen diberikannya perlakuan menggunakan model pembelajaran Course Review Horay berbantuan media visual dan pada kelompok kontrol tidak diberikannya perlakuan menggunakan model pembelajaran Course Review Horay berbantuan media visual selanjutnya akan dilakukan pengukuran. Analisis data dilakukan pada masing-masing kelas yaitu kelas ekperimen dan kelas kontrol. Hasil rekapitulasi data statistik deskriptif disajikan pada Tabel 2 berikut.

Tabel 2. Rekapitulasi hasil Perhitungan Skor Hasil Belajar Matematika

\begin{tabular}{lll}
\hline Statistik Deskriptif & Kelompok Ekperimen & Kelompok Kontrol \\
\hline Mean & 14,41 & 12,34 \\
\hline Median & 14,67 & 11,32 \\
\hline Modus & 15,5 & 11,17 \\
\hline Varians & 6,05 & 5,90 \\
\hline Standar Deviasi & 2,46 & 2,34 \\
\hline Skor minimum & 9 & 9 \\
\hline Skor maximum & 18 & 17 \\
\hline Rentangan & 10 & 9 \\
\hline
\end{tabular}

Data hasil belajar matematika di peroleh dari kelas ekperimen melalui post-test terhadap 22 orang siswa bahwa skor tertinggi adalah 18 dan skor terendah adalah 9. Dari skor yang diperoleh dapat dideskripsikan, yaitu mean $(\mathrm{M})=14,41$, berdasarkan dengan skala penilaian hasil belajar kelompok ekperiman berada pada rentang skor $13,5<\bar{X}_{\leq 18}$ dengan kategori sangat baik . Data hasil belajar matematika di peroleh dari kelas kontrol melalui post-test terhadap 19 orang siswa bahwa skor tertinggi adalah 17 dan skor terendah adalah 9. Dari skor yang diperoleh dapat dideskripsikan, yaitu mean $(\mathrm{M})=$ 
12,34 , , berdasarkan dengan skala penilaian hasil belajar kelompok kontrol berada pada rentang skor 10,5 $<\bar{X} \leq 13$ dengan kategori baik.

Uji normalitas sebaran data dilakukan untuk menyajikan bahwa sampel benar-benar dari populasi yang berdistribusi normal. Uji normalitas sebaran data dilakukan terhadap data hasil belajar matematika kelompok ekperimen dan kelompok kontrol. Berdasarkan analisis data yang telah dilakukan, dapat disajikan rekapitulasi hasil uji normalitas data hasil belajar matematika kelompok ekperimen dan kelompok kontrol pada Tabel 3.

Tabel 3. Rekapitulasi Hasil Uji Normalitas Distribusi Hasil Belajar Matematika

\begin{tabular}{lllll}
\hline No & Kelompok Data Hasil Belajar & $\mathbf{X}^{{ }^{2} \text { hitung }}$ & $\mathbf{X}^{\mathbf{2}_{\text {tabel }} \text { Taraf Signifikan }}$ & Status \\
\hline 1 & Post-test Ekperimen & 2,05 & 5,99 & Normal \\
\hline 2 & Post-test kontrol & 1,84 & 5,99 & Normal
\end{tabular}

Berdasarkan hasil perhitugan dengan menggunakan rumus chi-kuadrat, diperoleh $\mathrm{X}^{2}$ hitung kelompok ekperimen sebesar 2,05 dan $\mathrm{X}^{2}$ tabel dengan taraf signifikan $5 \%$ dan db = k-3 adalah 5,99 (k banyaknya kelas interval). Ini berarti $\mathrm{X}^{2}$-hitung lebih kecil daripada $\mathrm{X}^{2}$-tabel, dengan demikian data posttest kelas ekperimen berdistribusi normal. Sedangkan hasil perhitungan kelompok kontrol diperoleh diperoleh $\mathrm{X}^{2}$ hitung kelompok kontrol sebesar 1,84 dan $\mathrm{X}^{2}$ tabel dengan taraf signifikan $5 \%$ dan db=k-3 adalah 5,99 (k banyaknya kelas interval). Ini berarti $\mathrm{X}^{2}$-hitung lebih kecil daripada $\mathrm{X}^{2}$-tabel, dengan demikian data posttest kelas ekperimen berdistribusi normal.

Dalam penelitian ini uji homogenitas dilakukan dengan menggunakan uji $\mathrm{F}$ dengan kreteria Fhit>Ftab. Rekapitulasi hasil uji homogenitas varians antar kelomok ekperimen dan kontrol dapat disajikan pada Tabel 4.

Tabel 4. Hasil Uji Homogenitas Varians antar Kelompok Ekperimen dan Kelompok Kontrol

\begin{tabular}{llllll}
\hline \multicolumn{1}{c}{ Data } & & & $\mathbf{F}_{\text {hitung }}$ & $\mathbf{F}_{\text {tabel }}$ & Kesimpulan \\
\hline $\begin{array}{l}\text { Post-Test Kempok } \\
\text { Kelompok Kontrol }\end{array}$ & Ekperimen & dan & 1,03 & 2,18 & Homogen
\end{tabular}

Berdasarkan tabel di atas diproleh Fhitung hasil belajar kelompok ekperimen dan kelompok kontrol adalah 1,03 sedangkan Ftabel pada df pembilang $=21$ dan df penyebut 18 . Ftabel $=F(0,05 ; 21 ; 18)$ $=2,18$. Hal ini berarti Fhitung< Ftabel data posttest mempunyai varians yang sama atau homogen.

Berdasarkan Uji prasyarat dalam analisis data, diperoleh bahwa data hasil belajar matematika kelompok ekpermen dan kelompok kontrol adalah normal dan varians kedua kelompok homogen sehingga untuk menguji hipotesis menggunakan uji-t sampel independen dengan rumus polled varians. Rekapitulasi hasil perhitungan uji-t antar kelompok ekperimen dan kelompok kontrol disajikan pada Tabel 5.

Tabel 5. Rekapitulasi Hasil Perhitungan Uji-t

\begin{tabular}{lllllll}
\hline Kelompok & $\mathbf{N}$ & $\mathbf{M}$ & $\mathbf{S}_{\mathbf{1}}{ }^{\mathbf{2}}$ & $\mathbf{S}_{\mathbf{2}}{ }^{\mathbf{2}}$ & $\mathbf{t}_{\text {hitung }}$ & $\begin{array}{l}\mathbf{T}_{\text {tabel }} \\
\text { signifkan 5\% }\end{array}$ \\
\hline Eksperimen & 22 & 14,41 & 6,05 & & 2,65 & 2,02 \\
\hline Kontrol & 19 & 12,34 & & 5,90 & & \\
\hline
\end{tabular}

Berdasarkan Tabel 5 hasil analisis uji-t diperoleh $t_{\text {hitung }}=2,65$ sedangkan nilai $t_{\text {tabel }}$ pada taraf signifikan 5\% dengan derajat kebebasan $(n 1+n 2-2)=22+19-2=39$ adalah 2,02, Berdasarkan $t_{\text {hitung }}=$ 2,65 $>\mathrm{t}_{\text {tabel }}=2,02$ maka $\mathrm{H}_{0}$ ditolak atau terdapat pengaruh yang signifikan siswa yang mengikuti model pembelajaran Course Review Horay berbantuan media visual terhadap hasil belajar matematika siswa kelas IV SDN di gugus VII Kecamatan Abang Kabupaten Karangasem Tahun Pelajaran 2019/2020.

Menurut Astuti dan Mannahali (2018) Course Review Horay (CRH) merupakan model pembelajaran dengan menggunakan strategi games, apabila siswa dapat menjawab soal secara benar maka siswa tersebut diwajibkan meneriakan kata "hore" ataupun yel-yel yang disukai dan telah disepakati oleh kelompok maupun individu siswa itu sendiri.Nurhadi dan Sari (2019) Model pembelajaran ini memerlukan perencanaan dan pelaksanaan yang cukup, pada tahap pelaksanaan peserta didik dituntut aktif dalam proses belajar mengajar, dalam proses ini guru berperan sebagai fasilitator. Sejalan dengan 
pendapat Elah dan Muhammad (2019) yaitu bahwa peningkatan kemampuan pemahaman konsep matematika siswa yang menggunakan model course review horay lebih baik daripada kemampuan pemahaman konsep matematika siswa dengan menggunakan pembelajaran biasa.

Berdasarkan hasil penelitian dan pengujian hipotesis yang telah dilaksanakan model pembelajaran Course Review Horay berbantuan media visual terdapat pengaruh yang signifikan hadap hasil belajar matematika, disebabkan karena perbedaan perlakuan pada tahap-tahap proses pembelajaran. tahap pertama penyampaian kompetensi yang akan dicapai. Setelah guru melaksanakan kegiatan pembuka selanjutnya guru menyampaikan informasi kompetensi yang harus di capai oleh siswa agar proses pembelajaran dapat berjalan sesuai yang diharapkan.

Tahap kedua memberikan peluang kepada siswa untuk ikut terlibat langsung dalam proses pembelajaran, Maryam, et all (2016) menyatakan model pembelajaran Course Review Horay merupakan model pembelajaran yang dapat mendorong siswa ikut aktif terlibat langsung dalam belajar matematika. Model pembelajaran ini merupakan cara belajar-mengajar yang lebih menekankan pada pemahaman materi yang diajarkan guru dengan menyelesaikan soal-soal. pada tahap ini guru akan menyampaikan apersepsi dan materi yang di belajarkan dengan bantuan media visual berupa slide. Setelah penyampaian materi siswa diberikan kesempatan untuk bertukar pendapat dengan teman sebangku kemudian guru mengadakan tanya jawab dengan siswa agar materi dapat di pahami dengan baik.

Tahap ketiga menguji pemahaman siswa dan daya berpikir kritis siswa melalui kegiatan kelompok. Siswa akan dibagi dengan beberapa kelompok tiap kelompok terdiri 4-5 orang secara heterogen kemudian guru meminta siswa membuat kartu atau kotak sesuai dengan kebutuhan. Guru membaca soal secara acak dan siswa menuliskan jawabannya di dalam kartu atau kotak. Guru dan siswa mendiskusikan soal yang telah diberikan. Kalau benar didisi tanda check list $(\sqrt{ })$ dan kalau salah di beri tanda $(\mathrm{x})$. Pada tahap ini konsentrasi siswa sangat penting dan kerjasama antar kelompok, setiap siswa akan saling berusaha membantu dan memberikan jawaban terbaik. Selain itu memberikan semangat bagi siswa pembelajran menjadi tidak membosankan setiap siswa akan berperan aktif dalam proses pembelajaran

Tahap keempat pada tahap terakhir guru memberikan reward kepada kelompok yang mendapat nilai tertinggi. Setiap sisswa mendapat tanda check list $(\sqrt{ })$ harus berteriak horee atau yel yang lainnya. Guru menghitung nilai siswa, dihitung jawaban yang benar dan yang banyak berteriak "horee!!" kemudian guru memberikan reward pada kelompok yang memperoleh nilai tertinggi atau yang paling sering memperoleh "horee!!". pada tahap ini akan memberikan semangat siswa untuk belajar karena proses pembelajaran sangat menarik. Dengan diberikan reward siswa akan menjadi termotivasi untuk belajar kedepannya.

Hal ini sejalan dengan pendapat shoimin (2014) yang menyatakan, "kelebihan model pembelajaran Course Review Horay adalah model ini sangat menarik sehingga mendorong siswa terlibat didalamnya. Dalam proses pembelajaran tidak menoton karena diselingi dengan hiburan sehingga suasana belajar tidak menegangkan. Membangkitkan semangat siswa dalam belajar. Melatih kerja sama siswa dalam proses belajar, melatih daya ingat dan konsentrasi siswa

Hasil penelitian ini didukung oleh penelitian yang relevan yaitu penelitian yang dilakukan oleh Prameswari dkk (2017) adapun hasil penelitian yang didapatkan 1) Penguasaan kompetensi pengetahuan IPA siswa yang dibelajarkan melalui model pembelajaran CRH berbantuan media lingkungan sekolah menunjukan nilai rata-rata kelas sebesar 79,18 dengan skor tertinggi 100 dan skor terendah 54, varians sebesar 145,89 dan standar deviasi sebesar 12,1 nilai modus sebesar 85,5 dan nilai median sebesar 80. 2) penguasaan kompetensi pengetahuan IPA siswa yang dibelajarkan melalui pembelajaran konvensional menunjukkan nilai rata-rata kelas sebesar 73,8 dengan skor tertinggi 96 dan skor terendah 50 varians sebesar 135,76 dan standar deviasi sebesar 11,65, nilai modus sebesar 73,65 dan nilai median sebesar 73,65. 3) Terdapat perbedaan antara penguasaan kompetensi pengetahuan IPA antarasiswa yang dibelajarkan melalui model pembelajaran CRH berbantuan media lingkungan sekolah dengan yang dibelajarkan melalui pembelajaran konvensional, hal ini dibuktikan dengan hasil analisis uji t diperoleh thitung $=2,344$, dengan menggunakan taraf signifikan $5 \% \mathrm{dan} d \mathrm{dk}=65$. Sehingga thitung $=2,344>$ ttabel $=$ 1,980 .

Dengan didukung dengan penelitian yang relevan dan berdasarkan penelitan yang dilakukan maka model pembelajaran Course Review Horay berbantuan media visual sangat berpengaruh terhadap hasi belajar siswa. Berbeda halnya dengan model yang tidak menggunakan model pembelajaran Course Review Horay berbantuan media visual memiliki ciri pembelajarannya berpusat kepada guru sehingga siswa menjadi kurang aktif dalam proses pembelajarannya dengan menggunkan model pembelajaran konvemsional. Model pembelajaran konvemsional adalah pembelajaran yang digunakan oleh guru dalam proses pembelajarannya sangat umum dan belum termotivasi. Dalam peembelajaran konvensional guru yang berperan aktif, sedangkan siswa berperan sangat pasif dalam mengikuti pembelajarannya serta 
kurang mengaitkan dengan kehidupan sehari-hari sehinnga pembelajaran menjadi kurang bermakna. Hal itu yang menyebabkan pembelajaran menjadi kurang kondusif.

Perbedaan proses belajar mengajar dengan memberikan model pembelajaran Course Review Horay berbantuan media visual dan pembelajarannya yang tidak menggunakan model pembelajaran Course Review Horay berbantuan media visual akan memberikan dampak yang sangat berbeda terhadap hasil belajar matematika siswa. Hal ini dapat dilihiat dari skor yang diperoleh siswa yang pembelajarannya menggunkan model Course Review Horay berbantuan media visual skornya lebih tinggi dari siswa yang pembelajarannya tidak menggunakan model pembelajaran Course Review Horay berbantuan media visual. Nurhayati dan Marliani (2018) menyatakan pada realitanya dalam model pembelajaran Course Review Horay peserta didik tidak hanya belajar keterampilan dan isi akademik tetapi kerjasama yang menumbuhkan sikap yang positif di antara sesama peserta didik.

Hasil penelitian ini sejalan dengan penelitan tentang penerapan model pembelajaran Course Review Horay .Menurut Arsani, et all (2018) secara harfiah, Course Review Horay berasal dari bahasa inggris terdiri dari 3 kata yaitu Course yang berarti arah, tujuan mata kuliah, sajian, kuliah, rangkaian pelajaran, mata pelajaran. Review berarti tinjauan, resensi, meninjau, ulasan ulang, sedangkan Horay yaitu berarti hore, kata seru untuk menyatakan rasa gembira. Jadi Course Review Horay adalah sebuah pembelajaran dengan memberikan sajian/rangkaian pelajaran kemudian memberikan ulasan dengan tinjauan kembali dan merayakannya berteriak hore. Menurut Wahyuningtyas (2020) model pembelajara yang mampu menciptakan suasana kelas ramai tetapi tetap kondusif dan menarik keaktifannya, yaitu model pembelajaran kooperatif tipe Course Review Horay .

Sejalan dengan penelitian Utami (2016), hasil penelitiannya yang berjudul " Pengaruh Model Pembelajaran Course Review Horay (CRH) Berbantuan Media Konkret Terhadap Hasil Belajar IPA". Hasil penelitian ini menunjukan model pembelajaan Course Review Horay berbantuan media konkret berpengaruh terhadap hasil belajar IPA siswa kls V SD gugus VI kecamatan Sukasada. Sejalan dengan penelitian Aprizan, et all (2020) dengan judul penelitian "Meningkatkan Aktivitas Dan Hasil Belajardengan Model Course Review Horay (Crh)Di Sekolah Dasar". Hasil penelitian menunjukan bahwa bahwa penerapan model Course Review Horay(CRH) dapat meningkatkan aktivitas belajar siswa.

Dengan demikian model pembelajaran Course Review Horay berbantuan media visual berpengaruh terhadap hasil belajar matematika pada kelas IV di gugus VII kecamatan Abang.

\section{KESIMPULAN}

Berdasarkan hasil temuan dapat disimpulkan bahwa model pembelajaran Course Review Horay berbantuan media visual terdapat pengruh yang signifikan terhadap hasil belajar matematika di Gugus VII kecamatan abang tahun pelajaran 2019/2020 Saran yang dapat disampaikan berdasarkan penelitian yang telah dilakukan adalah sebagai beriut. Sisiwa-siswi di sekolah dasar agar lebih aktif dan semangat dalam proses pembelajaran yang dilakukan. Para guru disekolah dasar agar lebih kreatif dalam melaksanakan proses pembelajaran agar dapat meningkatkan hasil belajar siswa. Sekolah yang mengalami permasalahan hasil belajar matematika. Disarankan dapat mengimplementasikan model pembelajaran Course Review Horay dan media visual. Bagi peneliti yang berminat mengadakan penelitian lebih lanjut tentang model pembelajaran Course Review Horay dan media visual dalam pembelajaran matematika maupun yang lainnya agar memperhatikan kendala yang dialami dalam penelitian ini, sebagai bahan pertimbangan untuk perbaikan dan penyempurnaan penelitian yang akan dilaksanakan.

\section{DAFTAR PUSTAKA}

Aprilianawati, D. M., Nizaruddin, N., \& Prayito, M. (2019). Efektivitas Model Pembelajaran Kooperatif Tipe Course Review Horay Berbantuan Lectora Ditinjau dari Gaya Belajar terhadap Prestasi Belajar Matematika Siswa. Imajiner: Jurnal Matematika Dan Pendidikan Matematika, 1(6), 357.

Astuti, A., \& Mannahali, M. (2018). Peningkatan Keterampilan Menulis Kalimat Bahasa Jerman Siswa Menggunakan Model Pembelajaran Course Review Horay (Crh). Eralingua: Jurnal Pendidikan Bahasa Asing Dan Sastra, 2(1), 1-8.

Arsani, W. N., Putra, S. K. N. B. D., \& Ardana, K. I. (2013). Pengaruh Model Pembelajaran Course Review Horay Terhadap Hasil Belajar IPA Siswa Kelas IV. Mimbar PGSD, 1(3), 2.

Dantes, N. 2017. Desain Eksperimen dan Analisis Data. Depok: Rajawali Pers. 
Elah, \& Muhammad, G. M. (2019). Peningkatan Kemampuan Pemahaman Konsep Siswa SMP Melalui Model Pembelajaran CRH ( Course Review Horay) Increasing Conceptual Understanding of Junior High Schools Students Through the CRH ( Course Review Horay ) Learning Model To cite this article : Penin. Triple S: Jounrnals of Mathematics Education, 2, 33-44.

Faradipta. 2017. Pengaruh Model Pembelajaran Kooperatif Tipe Course Review Horay Terhadap Motivasi Belajar Siswa Mata Pelajaran Ipa Di Sekolah Dasar Jurnal Pendidikan dan Pembelajaran Sekolah Dasar. Volume 1, Nomor 2b (185-191).

Hasibuan, L. R. (2019). Pengaruh Model Pembelajaran Kooperatif Tipe Course Review Horay (CRH) Terhadap Hasil Belajar Matematika Siswa pada Materi Persamaan Linear Satu Variabel di Kelas VII SMP Negeri Rantau Selatan. Jurnal Pembelajaran Dan Matematika Sigma (Jpms), 5(1), 11-15.

Jayanti, D. D. (2017). Pembelajaran Course Review Horay : Sebuah Solusi Memperbaiki Prestasi Belajar Matematika Siswa. Jurnal Edukasi, 3(2), 175-184.

Jatiyasa, W. I. (2020). Peningkatan Keterampilan Menulis Aksara Bali (Permulaan) melalui Model Pembelajaran Course Review Horay (CRH) pada Siswa Kelas III SDN 3 Tiyingtali Tahun pelajaran 2019/2020. 11(2), 1-12.

Kusfabianto, I. J., Kristin, F., \& Anugraheni, I. (2019). Penerapan model pembelajaran Course Review Horay untuk meningkatkan keaktifan dan hasil belajar matematika kelas IV SD. Jurnal Teori Dan Aplikasi Matematika, 3(2), 87-92.

Maryam, S., Hasbi, M., \& Hamid, A. (2016). Penerapan Model Pembelajaran Kooperatif Tipe Course Review Horay Untuk Meningkatkan Hasil Persegi Panjang Di Kelas Vii Smp Negeri 2 Marawola. Jurnal Elektronik Pendidikan Matematika Tadulako, 04(01), 116-130.

Mediati, S. 2016. "Penggunaan Model Pembelajaran Course Review Horay Dengan Media Flipchart Sebagai Upaya Meningkatkan Hasil Belajar PKn". Jurnal Ilmiah Sekolah Dasar. Volume 1, Nomor 2 (hlm 113-121)

Nurhadi, \& Sari, S. S. (2019). Pengaruh Model Course Review Horeydengan Teknik Kerja Kelompok Terhadap Hasil Belajar Siswa Kelas XI Ma Al-Maarif Tebing Tinggi Barat Kabupaten Kepulauanmeranti Nurhadi1. Jurnal Online Mahasiswa : Pendidikan Matematika, 1(2), 80-94.

Ningrum, W. K., Putu, L., Mahadewi, P., \& Japa, I. G. N. (2019). Pengaruh Model Pembelajaran Course Review Horay Terhadap Keaktifan dan Hasil Belajar Matematika. 2(2), 209-218.

Naharir, R. A., Dantes, N., \& Kusmariyatni, N. (2018). Pengaruh Model Pembelajaran Course Review Horay Berbantuan Media Video Pembelajaran Terhadap Hasil Belajar Matematika Siswa Kelas V Semester II SD Gugus VI Kecamatan Sukasada Kabupaten Buleleng Tahun Pelajaran 2017 / 2018. Mimbar PGSD Undiksha, 6(1), 15-21.

Nureva, N., \& Wulandari, S. (2019). Pengaruh Model Pembelajaran Course Review Horay (CRH) Terhadap Hasil Belajar Siswa. Jurnal Iqra' : Kajian Ilmu Pendidikan, 4(1), 15-27.

Nurhayati, \& Marliani, N. (2019). Implementasi Model Pembelajaran Kooperatif Tipe Course Review Horay ( $\mathrm{CRH}$ ) Terhadap Kemampuan Pemecahan Masalah Matematika. JKPM (Jurnal Kajian Pendidikan Matematika), 5(1), 29-36.

Prameswari, W, dkk. 2017. " Pengaruh Model Pembelajaran Course Review Horay (Crh) Berbantuan Media Lingkungan Sekolah Terhadap Kompetensi Pengetahuan Ipa Siswa Kelas V Sd Gugus Kompyang Sujana Kecamatan Denpasar Utara”. e-Journal PGSD Universitas Pendidikan Ganesha. 2(2), 1-11.

Putri, N. L., Suastika, K. I., \& W. T. D. (2019). Pengaruh Media Batang Napier Pada Model Course Review Horay (CRH) Terhadap Hasil Belajar Matematika Siswa Kelas III Di SDN Bandungrejosari 03 Malang Lidya. Seminar Nasional PGSD UNIKAMA, 3, 149-157. 
Sadiman, dkk. 2012. Media Pendidikan pengertian, pengembangan, dan pemanfaatanya. Depok: Rajawali pers.

Shoimin, A. 2014. 68 model Pembelajaran Inovatif dalam Kurikulum 2013.Yogyakarta. Ar-ruzz media

Sundari. 2016. Meningkatkan Hasil Belajar Siswa Dalam Pembelajaran Matematika Melalui Pendekatan Savi Pada Siswa Kelas Vb Sdit Al-Izzah Sorong. Jurnal Pendidikan. Volume 5 Nomor 2 (44-51)

Sapta. 2016 Pengaruh Penggunaan Quiz Creator Terhadap Hasil Belajar Matematika Siswa. Jurnal mathematic paedagogic. Volume 1 Nomor 1. (hlm 91-96) Suriati, N. Y., Alzaber, \& Wahyuni, P. (2019). Penerapan model pembelajaran kooperatif tipe Course Review Horay (CRH) untuk meningkatkan hasil belajar matematika siswa kelas IX SMP Swasta Yayasan Pendidikan Persada Indah Perawang. Jurnal Aksiomatik, 7(20), 18-24.

Utami, P. D. K. S., Tastra, D. K., \& Kusmariyatni, N. (2016). Pengarug Model Pembelajaran Course Review Horay (CRH) Berbantuan Media Benda Kongkrit Terhadap Hasil Belajar IPA. E-Journal PGSD Universitas Pendidikan Ganesha, 4(1), 1-11.

Wahyuningtyas, C. D. (2020). Pengaruh Model Pembelajaran Course Review Horay ( CRH ) Terhadap Hasil Belajar Siswa Pada Kompetensi Dasar Memahami Administrasi Kelas OTKP SMK Negeri 10 Surabaya. Jurnal Pendidikan Administrasi Perkantoran (JPAP, 8(2), 340-350.

Wiyoksono, T., Aprizan, \& Lokmono, P. (2020). Meningkatkan Aktivitas Dan Hasil Belajar Dengan Model Course Review Horay ( CRH ). Jurnal Muara Pendidikan, 5(1), 609-618. 